\title{
THE ANATOMY OF HERVIELLA
}

YATSUI (BABA 1930) AND H. AFFINIS BABA, 1960 (NUDIBRANCHIAEOLIDOIDEA)

$\operatorname{AUTHOR}(\mathrm{S})$ :

Baba, Kikutaro

\section{CITATION:}

Baba, Kikutaro. THE ANATOMY OF HERVIELLA YATSUI (BABA 1930) AND H. AFFINIS BABA, 1960 (NUDIBRANCHIA-EOLIDOIDEA). PUBLICATIONS OF THE SETO MARINE BIOLOGICAL LABORATORY 1966, 14(1): 1-6

ISSUE DATE:

1966-04-25

URL:

http://hdl.handle.net/2433/175427

RIGHT: 


\title{
THE ANATOMY OF HERVIELLA YATSUI (BABA 1930) AND H. AFFINIS BABA, 1960 (NUDIBRANCHIA-EOLIDOIDEA) ${ }^{1)}$
}

\author{
KIKUTARÓ BABA \\ Biological Laboratory, Osaka Gakugei University, Osaka
}

With Plates $I-I I$

The present paper was planned to give full accounts of the anatomy of yatsui BABA, 1930 and affinis BABA, 1960, both from our seas, in order to supply better conception of Herviella BABA, 1949, in the systematics of cleioproctic Eolidoidea, than before. Recently a third species of the same genus (H. claror) was found to occur in Australia by BuRN, 1963.

The author is indebted greatly to Messrs. Iwao Hamatani (Osaka Gakugei University) and Takeo ABE (Takaoka High School, Toyama Pref.) whose collections were added to the source of material for the present study.

\section{Herviella yatsui (BABA, 1930)}

$$
\text { (Pl. I, figs. 1-8; Pl. II, figs. 1-5) }
$$

Cratena yatsui BABA, 1930, pp. 121, 124, pl. 4, figs. 4a-4b, text-figs. 3a-3b.-Sagami Bay. Cuthona (Cuthona) yatsui BABA, 1937, p. 328, pl. 2, fig. 2.

Herviella yatsui BABA, 1949 , pp. 107-108, 180-181, pl. 47, figs. 159-161, text-figs. 145-146.Sagami Bay; ABE, 1964, pp. 70-71, pl. 34, fig. 121.-Toyama Bay, W. coast of Noto Peninsula, and Tsuruga Bay.

In our seas this species is widely spread on the Pacific coasts (Sagami Bay; Suruga Bay; Seto, Kii ; Osaka Bay; Amakusa) as well as on the Japan Sea side (Sado Is., Toyama Bay; W. coast of Noto Peninsula ; Tsuruga Bay). It is not rare, and specimens were obtained usually from underneath pebbles in the intertidal zone. The natural diet of this species was left unknown.

As far as allowed observation was made on live specimens collected by the author or by his friends from various stations. For the examination of internal organs, ten specimens listed below were prepared in serial sections stained usually by Delafield's haematoxylin and eosin, and sometimes by toluidine blue.

1) Contributions from the Seto Marine Biological Laboratory, No. 447.

Publ. Seto Mar. Biol. Lab., XIV (1), 1-6, $1966 . \quad$ (Article 1) 
Sp. Nos. 1-3. Loc.: Seto, Kii. Date: Jan. 5, 1950. (H. S.)

Sp. Nos. 4-5. Loc.: Ohkawa, Osaka Bay. Date: Aug. 27, 1961. (H. S.)

Sp. No. 6. Loc.: Seto, Kii. Date: Jan. 5, 1950. (L. S.)

Sp. Nos. 7-10. Loc.: Seto, Kii. Date: Jan. 5, 1950. (T. S.)

Of these, Sp. Nos. 1-3 and 7-10 were juvenile, and the rest showed each a fully matured state.

Externals: The general body-form and colours are approximately as reported before. The total length (Code Ac) is usually $6-12 \mathrm{~mm}$, and the maximum length reaches to $15 \mathrm{~mm}$. The cephalic tentacles are exceedingly slender. The rhinophores are shorter, and smooth in fresh. The foot-corners are rounded. The tail is long and tapering posteriorly. The branchial papillae are arranged always in simple oblique rows on either side. The following is an example of branchial formula taken from one of the mediumsized specimens (Code Ac $10 \mathrm{~mm}$ ) from the right and left sides: I (7-7), II (5-6), III (4-4), IV (3-3), V (2-2) and VI (1-1). The papillae themselves are elongated fusiform when fully extended, but contractile, and easily falling off. The genital orifices open immediately below the middle of the right liver row. The anus is found closely behind the posterior end of the first right row belonging to the left posterior liver, and certainly it represents the cleioproctic position of anus. The nephroproct lies a short distance in front of the anus.

The general integument of the body is of a translucent yellowish white, the back slightly pinkish owing to the viscera showing through, and the sole colourless. The characteristics in colouring of this species may be summarized as follows: (1) The head above is always marked with a black U-letter, its fore-ends passing along the lower halves of the cephalic tentacles which are opaque white distally. There may be an additional short longitudinal band of black on each head-side. (2) Always the rhinophores are provided each with a black band about half way down, and they are opaque white above. (3) The median part of the back is rather thickly covered with black spots. These latters are absent altogether from sides of body. There are additional spots of opaque white over the head, back, and sides. The tail has an opaque white streak in the median line. (4) The black spots on each of the branchial papillae are gathered in two clusters, an upper and a lower, and the upper cluster serves usually to form a black ring a short way down the apex of the papilla. Each papilla has also a broad, subapical band of opaque white just below the colourless tip. Often there is a second band of opaque white round the mid-length of the papilla.

The vein (=liver-diverticulum) within each of the papillae varies in tones from yellowish, yellowish green (olive), yellowish brown, to pinkish, according to different individuals. The mouth opening and the anterior margin of the foot are highly glandular, and opaque. 
Internals: The main characters of the jaw-plates and radula are as shown previously. Here two more specimens (Seto, Jan. 5, 1950) were dissected for the re-description of these structures. The jaw-plates are yellowish brown, and the jaw-edge bears a series of acute denticles, from $15-16$ to 20 in number in different specimens. The radula formula is $18-25 \times 0.1 .0$. The teeth are pale yellow, broadly horseshoe-shaped, and each is provided with (4-)5 denticles on either side of a strong median cusp. The liver system characterizes Herviella greatly: the right liver (and the left partner) is a single oblique canal provided with a row of branchial papillae and it does not constitute a horseshoe. The digestive tract proper is ciliated on the inner surface. The salivary glands are long and band-like. The stomach is without an accessory blind sac. The intestine is short, and bears an inner longitudinal ridge. The liver-diverticulum within each of the branchial papillae is a simple tube which passes into the cnidosac through a slender canal. The freshly isolated liver cells of the yellowish diverticulum appear to be in three sorts: (1) those with mostly small, ashy yellow granules, (2) those with coarse, colourless granules, and (3) those with refringent, yellow or yellowish brown granules. The fresh cnidocysts are packed with nematocysts, leaving no room for colourless droplets. The reno-pericardial canal is not thickly folded internally. The kidney is a simply elongated sac without branchings. As for the genital system, the presence of a penis stylet in Herviella was already pointed out by BURN, 1963 (p. 18). The penis stylet of $H$. yatsui in fresh is yellowish brown. It forms a short, curved hook which is armed with a row of 3-6 minute spines on the ventral edge in the median line. The penis itself in the contracted state is elongated conical, and highly muscular. There is no formation of an accessory penis gland. The distal half of the vas deferens is thick and prostatic, and passes into the penis as far as to the base of the stylet. The proximal part of the vas deferens is narrow and muscular. The ampulla is thick, but it is slightly coiled. The spermatheca is a spherical sac with a highly plicated inner wall. The genital orifices are separated. The general composition of the accessory genital complex is approximately as in Favorinus, Rizzolia and Facelinella. Each of the gonadial follicles generates both sperms and eggs.

Remarks: Two of the outstanding characters of Herviella refer to the liver system not forming horseshoes, and the muscular penis armed with an apical stylet. The systematic assignment of this genus to the Favorinidae is thus only provisional. And the known members of Herviella are subjected to slightest differentiation from one another in the details of body colouring, jaw-plates, radula teeth and penis stylet. 


\section{Herviella affinis BABA, 1960}

(Pl. II, figs. 6-11)

Herviella affinis BABA, 1960, pp. 303-305, text-fig. 1.-Osaka Bay and Toyama Bay; ABE, 1964, pp. 71,89 , pl. 35, fig. 126.-Toyama Bay.

In our waters this species is distributed on the Pacific coasts (Seto, Kii ; Osaka Bay) and on the Japan Sea side (Toyama Bay), but the actual specimens to be collected are rather scanty.

Re-examination studies were carried on some fresh or preserved material in the author's hand. Of these, two were sectioned as follows:

Sp. No. 11. Loc.: Kada, Osaka Bay. Date: Sept. 4, 1960. (H. S.)

Sp. No. 12. Loc.: Kada, Osaka Bay. Date: Oct. 31, 1959. (T. S.)

The main features of this species are as given previously. In this species there is no U-letter of black on the head. The cephalic tentacles are colourless above, or slightly yellow-tinted. The rhinophores have each a black band in about their mid-length (rarely this may be obsolete); they are always tinged with chrome yellow on the upper half. Black spots intermingled with opaque white ones are distributed everywhere on the head, back and sides. The median dorsal line of the tail is opaque white. The branchial papillae are opaque white above, black spotted below, and each one of them is marked with an orange ring down the tip. The veins (=liver-diverticulum) of the papillae are faintly yellowish or pinkish. The ground-colour of the body is yellowish white (more yellowish on the back) and the sole is colourless.

Concerning the constitution of the jaw-plates, radula teeth and penis stylet, there seems to be no marked difference between the two species, $H$. yatsui and $H$. affinis. In affinis, however, the denticles on the jaw-edge are rather coarse, and only $10-12$ in number. The ribbon of the radula is rather short. The teeth have each 3-4 flanking denticles; the median cusp is somewhat stouter than that in yatsui. The radula formula is $13-14 \times 0.1 .0$. The penis stylet is comparatively long, curved, and not armed with ventral spines. The other characters of the digestive organs and genital system are approximately as shown in $H$. yatsui.

Remarks: As already noted by Burn, 1963 (pp. 18-19), the Australian $H$. claror BURN, 1963 comes most closely to $H$. affinis, if not conspecific to the latter. From the illustrated figures of Aeolidia exigua RisBec, 1928 (pp. 245-246, pl. 10, fig. 8, text-fig. 77 ; see also RISBEc, 1953, p. 134) it is not easy to recognize this New Caledonian form as a Herviella.

\section{REFERENCES}

AвE, T. 1964. Opisthobranchia of Toyama Bay and adjacent waters. Hokuryu-kan, Tokyo. 
BABA, K. 1930. Studies on Japanese nudibranchs (3). Venus, vol. 2, no. 3.

1937. Opisthobranchia of Japan (II). Journ. Dept. Agric. Kyushu Imp. Univ., vol. 5 , no. 7 .

1949. Opisthobranchia of Sagami Bay. Iwanami Shoten, Tokyo:

1960. The genus Herviella and a new species, H. affinis, from Japan (NudibranchiaEolidacea). Publ. Seto Mar. Biol. Lab., vol. 8, no. 2.

BURN, R. 1963. Descriptions of Australian Eolidacea (Mollusca: Opisthobranchia). I. The genera Catriona and Herviella. Journ. Malac. Soc. Austr., no. 7.

Risbec, J. 1928. Contribution a l'étude des nudibranches Néo-Calédoniens. Faune Colon. Franç., tom. 2.

vol. 15.

Risso-Dominguez, C. J. 1963. Measuring nudibranchs: a standardization for descriptive purposes. Proc. Malac. Soc. London, vol. 35, pt. 5.

\section{EXPLANATION OF PLATES I-II}

\section{Plate I}

Figs. 1-8. Herviella yatsui.

Fig. 1. Living animal in actively crawling position. Material : Seto, Kii (June 28,1964 ). Length from cephalic tentacles to tail tip (Code A) $12 \mathrm{~mm}$; length from head to tail tip (Code Ac) $10 \mathrm{~mm}$; height of body (Code H) $1 \mathrm{~mm}$; length of tail (Code C) $3 \mathrm{~mm}$; length of cephalic tentacle (Code T) $4 \mathrm{~mm}$; length of rhinophore (Code R) $2.5 \mathrm{~mm}$; maximum length of papilla (Code $\mathrm{Px}$ ) $2 \mathrm{~mm}$.

Fig. 2. Fresh cnidocyst packed with nematocysts $(\times 270)$. Material: same as Fig. 1.

Fig. 3. Animal from ventral side. Material: same as Fig. 1. Showing protruded copulatory parts. a. male orifice, b. female orifice.

Fig. 4. Right jaw-plate from outside $(\times 27)$. Material : Seto, Kii (Jan. 5, 1950). Denticles of jaw-edge about 20 .

Fig. 5. A central tooth $(\times 140)$ from the proximal end of the radula ribbon (entire radula formula $1.8 \times 0.1 .0$ ). Material: same as Fig. 4. Denticles 5 .

Fig. 6. Three centrals $(\times 140)$ from the distal end of the radula ribbon. Material : same as Fig. 4.

Fig. 7. Digestive system in the body, diagrammatic. Material: Sp. No. 4. a. central nervous system, b. right liver, c. genital orifices, d. cross section of intestine, e. cross section of reno-pericardial canal, f. nephroproct, g. anus, h. left posterior liver, i. kidney, $j$. cross section of body on level of anus, $k$. left anterior liver, l. salivary gland.

Fig. 8. Freshly isolated liver cells $(\times 400)$. Material: same as Fig. 1. a. liver cells with small, ashy yellow granules, b. liver cells with coarse, colourless granules, c. liver cells with refringent, yellow or yellowish brown granules. 


\section{Plate II}

Figs. 1-5. Herviella yatsui.

Fig. 1. Genital system in the body, diagrammatic. Material: Sp. No. 4. a. male orifice, $b$. female orifice, $c$. nephroproct, d. anus.

Fig. 2. Genital organs from above, diagrammatic $(\times 40)$. Material : Sp. No. 4. a. muscular penis, b. male orifice, c. female orifice, d. outer oviduct, e. area of gland B (?=mucous gland), f. area of gland A $(?=$ albumen gland), g. spermatheca, h. hermaphrodite duct, i. ampulla, j. area of gland $\mathrm{C}(?=$ membrane gland $), \mathrm{k}$. inner oviduct $(?=$ fertilization chamber), 1. prostatic part of vas deferens. The gland A communicates with the gland $B$ on one hand, and opens into the outer oviduct on the other. On the ventral side of the genital mass, the glands B and $\mathrm{C}$ are completely united to pass into the outer oviduct.

Fig. 3. Distal male organ enlarged $(\times 90)$. Material: same as Fig. 2. a. prostatic part of vas deferens, b. muscular penis, c. penis stylet with 3 ventral spines, d. penis sheath.

Fig. 4. Penis stylet in fresh $(\times 130)$. Material: Seto, Kii (June 28, 1964). Showing a curved stylet with 6 ventral spines.

Fig. 5. A gonadial follicle $(\times 35)$. Material: Sp. No. 4. Generatiug both of the sperms and eggs.

Figs. 6-11. Herviella affinis.

Fig. 6. Living animal in actively crawling position. Material: Seto, Kii (June 28, 1964). Codes : A, $13 \mathrm{~mm}$; Ac, $11 \mathrm{~mm} ; \mathrm{H}, 1 \mathrm{~mm} ; \mathrm{C}, 3 \mathrm{~mm}$; T, $3 \mathrm{~mm}$; $\mathrm{R}, 2 \mathrm{~mm}$; Px, $3 \mathrm{~mm}$. The general body-form including the position of genital orifices and anus is quite as in H. yatsui. The papillae are elongated fusiform, but contractile, and the liver-diverticulum within each of them is simple.

Fig. 7. Left jaw-plate from outside $(\times 27)$. Material: Ohkawa, Osaka Bay (Aug. 20, 1959). Yellowish brown in colour. Denticles of jaw-edge 10.

Fig. 8. A central tooth $(\times 90)$. Material: same as Fig. 7. Yellowish brown in colour. Denticles $3-4$. Formula of the entire radula ribbon 13 $\times 0.1 .0$.

Fig. 9. Distal male organ enlarged $(\times 30)$, from above. Material: Sp. No. 11. a. muscular penis, b. penis stylet, c. penis sheath, d. muscular part of vas deferens, e. distal part of ampulla, f. prostatic part of vas deferens.

Fig. 10. Penis stylet enlarged ( $\times 85)$. Material: same as Fig. 9.

Fig. 11. Part of the genital organs in the horizontal section of the body $(\times 20)$, from above. Material: Sp. No. 11. Showing an act of egg-laying. a. female orifice, b. egg-string, c. area of gland B, d. gonadial follicle, e. spermatheca, f. ampulla, g. area of gland C. 
Publ. Seto Mar. Biol. Lab., XIV (1), 1966.
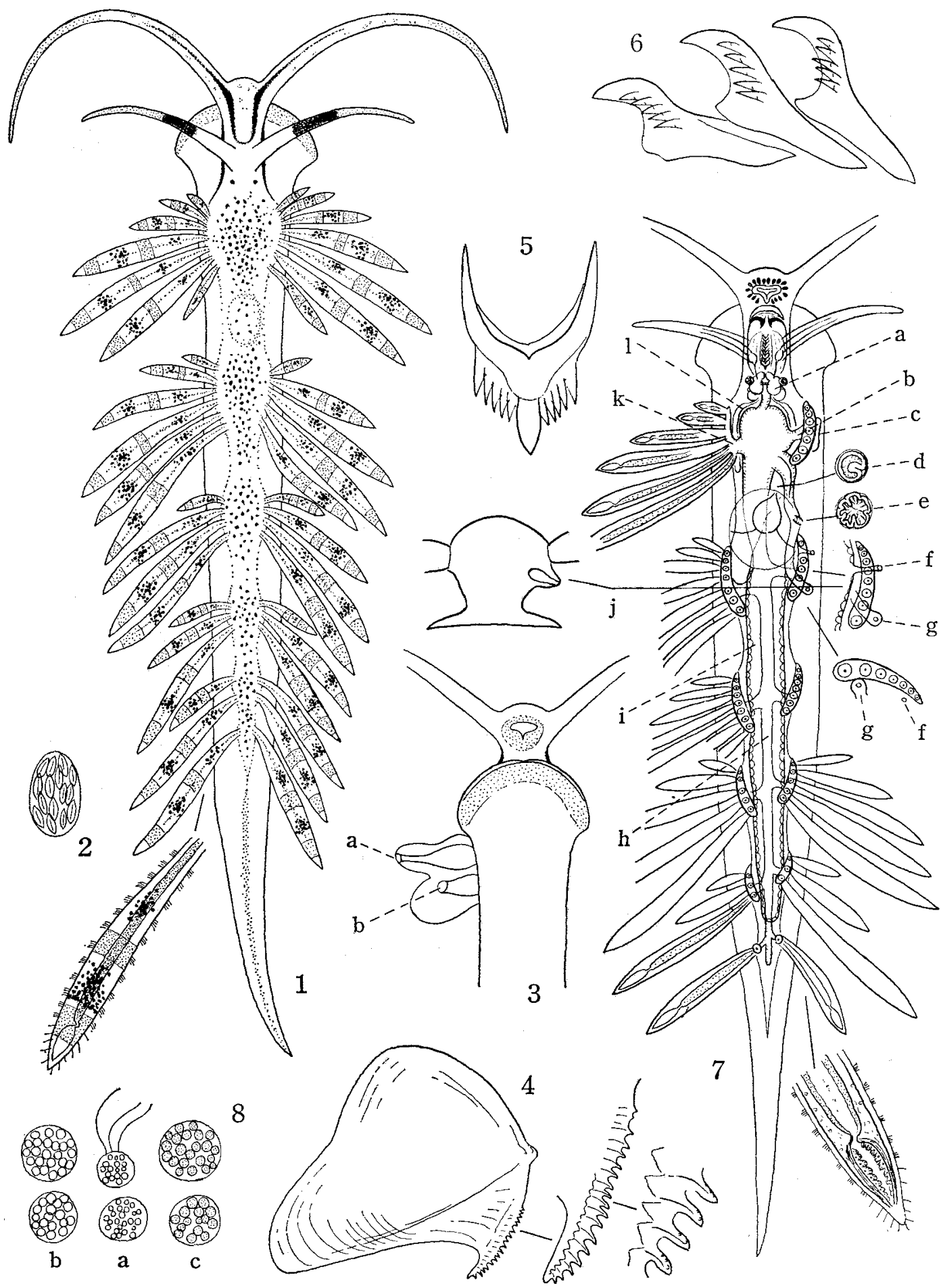

K. BABA : Anatomy of Herviella yatsui and $\mathrm{H}$. affinis. 
Publ. Seto Mar. Biol. Lab., XIV (1), 1966.

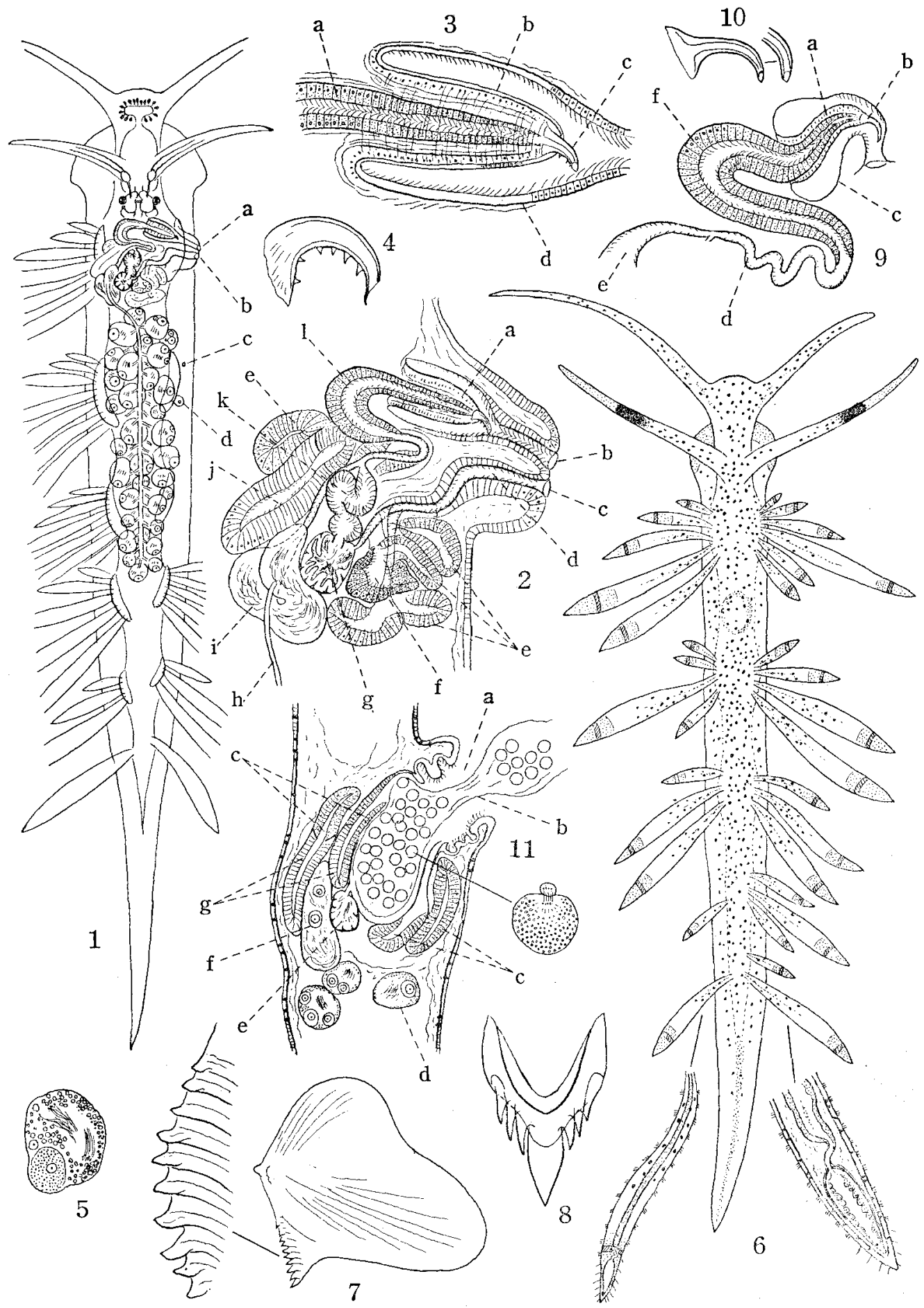

K. BABA: Anatomy of Herviella yatsui and $\mathrm{H}$. affinis. 